\title{
WYKROCZENIE NISZCZENIA LUB USZKADZANIA URZĄDZEŃ SŁUŻĄCYCH DO OCHRONY BRZEGÓW WÓD MORSKICH LUB ŚRÓDLĄDOWYCH (ART. 81 KODEKSU WYKROCZEŃ)
}

\section{Wstęp}

Wykroczenie z art. 81 Kodeksu wykroczeń (dalej: K.w.) to ciekawy przykład typu z narażenia na niebezpieczeństwo abstrakcyjne, który jednocześnie jest skutkowy. W doktrynie istnieją dwa podejścia do zagadnienia skutku w przypadku typów z narażenia dobra na niebezpieczeństwo abstrakcyjne. Ze szczególną ostrością pojawia się ono na gruncie czynów przeciwko środowisku takich jak omawiany albo czyn z art. 182 Kodeksu karnego (dalej: K.k.) ${ }^{1}$. Chodzi o to, jak rozumieć skutek - czy jest nim narażenie lub naruszenie przedmiotu ochrony, czy jakakolwiek przewidziana w przepisie zmiana w świecie zewnętrznym wywołana czynem, odrębna

* Dr hab., prof. Uniwersytetu Marii Curie-Skłodowskiej w Lublinie; e-mail: marek. kulik@poczta.umcs.lublin.pl, https:/ / orcid.org/0000-0003-0191-6558.

1 A. Marek, Prawo karne, Warszawa 2011, s. 428; D. Gruszecka, w: Kodeks karny. Część szczególna. Komentarz, red. J. Giezek, Warszawa 2014, s. 416, z poglądem, że jest to typ formalny; M. Kulik, w: Kodeks karny. Komentarz, red. M. Mozgawa, Warszawa 2017, s. 546; tenże, O skutkowym lub bezskutkowym charakterze czynów zabronionych przez art. 182 k.k., Annales Universitatis Mariae Curie-Skłodowska. Sectio G. Ius 2014, t. 61, nr 2, s. 99; M. Gałązka, w: Kodeks karny. Komentarz, red. A. Grześkowiak, K. Wiak, Warszawa 2018, s. 951-952; G. Bogdan, w: Kodeks karny. Komentarz. Część szczególna, t. 2, Kraków 2006, s. 510, z poglądem, że jest to typ materialny. Odrębne stanowisko zajmuje W. Radecki, który uważa, że czyn z art. 182 K.k. pozostaje - wraz z czynami z art. 183 § 1 K.k. i 184 § 1 K.k. - poza podziałem na typy formalne i materialne. W. Radecki, w: System prawa karnego. Przestępstwa przeciwko państwu i dobrom zbiorowym, red. L. Gardocki, Warszawa 2013, s. 482; tenże, w: M. Filar, Kodeks karny. Komentarz, red. M. Filar, Warszawa 2012, s. 909. 
odeń i istniejąca po jego zakończeniu ${ }^{2}$. Jeżeli przyjąć pierwsze rozumienie, należałoby uznać, że czyny z narażenia na niebezpieczeństwo abstrakcyjne są bezskutkowe ${ }^{3}$, jeżeli zaś drugie - wówczas byłyby to typy skutkowe $^{4}$. Przyjęcie wybranego poglądu jest funkcją założeń wyjściowych ${ }^{5}$. Rozstrzygniecie zaś tej kwestii niesie określone skutki, choćby w zakresie ustalenia, na czym polega dokonanie czynu. Trzeba dodać, że typ wykroczenia niszczenia lub uszkadzania urządzeń służących do ochrony brzegów nie jest przedmiotem większego zainteresowania doktryny, poza opracowaniami komentarzowymi, tymczasem jest on wart osobnego opracowania. Niniejszy tekst stanowi próbę krótkiego zarysowania najważniejszych problemów wykładniczych z nim związanych. W związku z takim określeniem celu opracowania uwagi dotyczące określenia czynności sprawczej czy przedmiotu tej czynności zostaną ograniczone do niezbędnego minimum, gdyż nie budzą specjalnych wątpliwości, zaś podmiot i strona podmiotowa nie będą omawiane w ogóle.

\section{Przedmiot ochrony}

Przyjmuje się, że szczególnym przedmiotem ochrony czynu $\mathrm{z}$ art. $81 \mathrm{~K} . w$. jest bezpieczeństwo życia i zdrowia ludzi oraz mienia ${ }^{6}$. Istnie-

2 W. Wolter, Zarys systemu prawa karnego. Część ogólna, t. 1, Kraków 1933, s. 54; tenże, Nauka o przestępstwie, Warszawa 1973, s. 65; W. Świda, Prawo karne, Warszawa 1989, s. 378; I. Andrejew, Ustawowe znamiona czynu. Typizacja i kwalifikacja przestępstw, Warszawa 1978, s. 189-190; tenże, Polskie prawo karne w zarysie, Warszawa 1986, s. 126; J. Giezek, w: M. Bojarski, J. Giezek, Z. Sienkiewicz, Prawo karne materialne. Część ogólna, Warszawa 2004, s. 98; M. Cieślak, Prawo karne. Zarys systematycznego ujęcia, Warszawa 1994, s. 163 i nn.; W. Wróbel, A. Zoll, Polskie prawo karne. Część ogólna, Kraków 2010, s. 194; D. Gruszecka, Ochrona dobra prawnego na przedpolu jego naruszenia. Analiza karnistyczna, Warszawa 2012, s. 87.

Zob. E. Hryniewicz, Przestępstwa abstrakcyjnego i konkretnego zagrożenia dóbr prawnych, Warszawa 2012, s. 164.

4 M. Kulik, O skutkowym lub bezskutkowym charakterze..., s. 96.

5 Zob. w szczególności rozbieżne stanowiska w tej mierze D. Gruszeckiej (Ochrona..., s. 87) i M. Kulika (O skutkowym lub bezskutkowym charakterze..., s. 99).

6 W. Radecki, w: M. Bojarski, W. Radecki, Kodeks wykroczeń. Komentarz, Warszawa 2016, s. 619; J. Piórkowska-Flieger, w: Kodeks wykroczeń. Komentarz, red. T. Bojarski, Warszawa 2015, s. 206; W. Jankowski, w: Kodeks wykroczeń. Komentarz, red. T. Grzegorczyk, 
je też pogląd, że są nim brzegi jako takie ${ }^{7}$, co jest tylko pośrednio związane $\mathrm{z}$ bezpieczeństwem osób i mienia. Rozumienie przedmiotu ochrony ukierunkowane jest na bezpieczeństwo, gdyż analizowany typ umieszczono w rozdziale obejmującym wykroczenia przeciwko bezpieczeństwu osób i mienia. Kierunkowanie szczególnego przedmiotu wynikające z umieszczenia typu w danym rozdziale sprawiło, że mniej widoczny stał się jego ekologiczny aspekt. Nie jest to jednak miejsce, by dyskutować z decyzją ustawodawcy. Omawiane wykroczenie ma jednak, obok aspektu ochrony życia, zdrowia i mienia, także aspekt ochrony środowiska. Wydaje się wręcz, że jest on bardziej bezpośredni niż ten, na który wskazuje lokalizacja przepisu. Okoliczność ta wiąże się z zasygnalizowanym wcześniej ujęciem skutku jako związanego lub nie z przedmiotem ochrony. W analizowanym typie skutek dotyka bezpośrednio urządzeń służących do ochrony brzegów wód, w szczególności umocnień lub roślinności ochronnej, a więc elementów niezwiązanych bezpośrednio z bezpieczeństwem osób i mienia.

W doktrynie często postrzega się przedmiot czynności wykonawczej jako swego rodzaju materialny substrat przedmiotu ochrony ${ }^{8}$. Zwykle tak właśnie jest, jednak nie oznacza to, że zawsze tak być musi - w danym przypadku jest bowiem inaczej. Przedmiot ochrony stanowi bezpieczeństwo życia i zdrowia rozumianego abstrakcyjnie. Konkretne zachowanie nie musi naruszać ani bezpośrednio narażać dobra ${ }^{9}$. Przedmiotem czynności wykonawczej są obiekty służące ochronie brzegów. Nie da się znaleźć bliskiego związku między przedmiotem ochrony a przedmiotem czynności wykonawczej, związek ten jest na tyle odległy, że można z powodzeniem wyobrazić sobie podobny, jeżeli nie bliższy, związek przedmiotu czynności wykonawczej z innym przedmiotem ochrony. To przede wszystkim umiejscowienie typu w K.w. zmusza do postrzegania szczególnego przedmiotu ochrony jako związanego z bezpieczeństwem osób i mienia. Na tym przykładzie łatwo zauważyć, że może istnieć typ skutkowy, będący jednocześnie czynem z narażenia na niebezpieczeństwo

Warszawa 2013, s. 343; M. Kulik, w: Kodeks wykroczeń. Komentarz, red. P. Daniluk, Warszawa 2018, s. 526.

7 P. Kozłowska-Kalisz, w: Kodeks wykroczeń. Komentarz, red. M. Mozgawa, Warszawa 2009, s. 283.

8 Zob. np. prace A. Marka, D. Gruszeckiej i W. Radeckiego powołane w przyp. 1. Tak też J. Piórkowska-Flieger, Skutek czynu zabronionego w polskim prawie karnym, Lublin 2019, s. 86-87.

9 P. Kozłowska-Kalisz, w: Kodeks wykroczeń..., red. M. Mozgawa, s. 283-284. 
abstrakcyjne. Dobro chronione nie zostaje naruszone ani bezpośrednio narażone, jednak następuje zmiana $\mathrm{w}$ świecie zewnętrznym wymagana przez przepis.

Zmiana, o której mowa, nie dotyka przedmiotu ochrony, ale zwykle odnosi się do jakiegoś dobra. Nie znaczy to, że dobro to jest przedmiotem ochrony, niekiedy staje się ono ubocznym przedmiotem ochrony, innym razem nie - $\mathrm{i}$ wtedy pozostaje $\mathrm{w}$ tle. $\mathrm{W}$ przypadku omawianego czynu środowisko nie jest przedmiotem ochrony, w każdym razie nie głównym, gdyż można uzasadniać pogląd, że jest przedmiotem ubocznym. Jednak nawet gdyby uznać, że środowisko naturalne nie jest ani głównym, ani ubocznym przedmiotem ochrony, jego ochrona pojawia się na gruncie typu, a jeśli nie wprost, to w tle - na poziomie ratio legis. Ratio legis zwykle wiąże się z przedmiotem ochrony, ale nie zawsze wprost i niekoniecznie tylko z nim. Może to być przedmiot ochrony wyrażony w treści danego przepisu, lecz także ukryty, leżący u podłoża typizacji.

Nie jest to dokładnie ujęcie charakterystyczne dla typizacji nazwanej przez L. Gardockiego uproszczoną ${ }^{10}$, ale wykazuje ono pewne istotne podobieństwa. Jako przykład uproszczonej typizacji podaje się wprowadzanie typów formalnych tam, gdzie chodzi o ochronę pewnego dobra ${ }^{11}$. Tu mamy nieco inną sytuację. Przedmiotem ochrony jest bezpieczeństwo osób i mienia, bo wprost przesądził o tym ustawodawca. Przedmiot ten nie musi być naruszony ani bezpośrednio narażony - narażenie ma charakter abstrakcyjny. Jest z nim połączony drugi, na który nie wskazuje umiejscowienie przepisu, ale który wynika z określenia czynności wykonawczej i jej przedmiotu - jest nią należyty stan brzegów wód morskich i śródlądowych, a zatem wartość o charakterze przyrodniczym. Autor niniejszego tekstu jest skłonny uważać wartość przyrodniczą co najmniej za dodatkowy przedmiot ochrony, jednak nawet gdyby nie podzielać tego poglądu, nie sposób nie dostrzec, że wartość ta leży u podłoża typizacji.

Ma to znaczenie praktyczne. Konstrukcja typu sprawia, że stosunkowo często analizowany przepis będzie występował w zbiegu z przepisami typizującymi czyny o charakterze ekologicznym. Pojawia się pytanie, czy zawsze analizowany zbieg będzie rzeczywisty właściwy, czy też wspomniane pokrewieństwo tego typu z czynami przeciwko środowisku

10 L. Gardocki, Typizacja uproszczona, Studia Iuridica 1982, t. 10, s. 71 i nn.; tenże, Uproszczone formy penalizacji, Państwo i Prawo 1975, z. 8-9, s. 68 i nn.

11 L. Gardocki, Typizacja..., s. 77 i nn. 
naturalnemu nie skłania, by w niektórych wypadkach zbiegu rzeczywistego uznać go za pomijalny na zasadzie konsumpcji12.

Trzeba uwzględnić jeszcze jedną istotną okoliczność, która jednak może stać się jasna dopiero po przyjrzeniu się problematyce przedmiotu czynności wykonawczej. Wyżej wskazano, że w doktrynie pojawiają się poglądy, zgodnie z którymi przedmiot czynności wykonawczej stanowi swego rodzaju materialny substrat przedmiotu ochrony ${ }^{13}$, niemniej wydaje się, że tak nie jest. Oczywiście zależy to od przyjętej definicji skutku, a ta siłą rzeczy nie może być postrzegana jako element stały i niezmienny, gdyż ma charakter pozaustawowy ${ }^{14}$. To rodzi szereg konsekwencji dogmatycznych, także i te, że pojęcie skutku bywa interpretowane bardzo różnie, a jego stosunek do przedmiotu ochrony bardzo różnie traktowany.

12 Zob. niżej.

13 Zob. prace powołane w przyp. 1 i 8.

14 E. Hryniewicz, Skutek w prawie karnym, Prokuratura i Prawo 2013, nr 7-8, s. 108. W doktrynie zwraca się - zresztą słusznie - uwagę, że problematyka rozstrzygnięcia, czym jest skutek, jest w pewnym sensie niedoceniana (S. Tarapata, Przypisanie sprawstwa skutku w sensie dynamicznym w polskim prawie karnym, Kraków 2019, s. 72). Wyjątkiem jest praca J. Piórkowskiej-Flieger, w całości poświęcona temu zagadnieniu, gdzie podejmuje się próbę zdefiniowania skutku jako takiego. W interesującym nas tu zakresie ważne są wywody autorki dotyczące stosunku skutku do dobra prawnego (Skutek czynu zabronionego..., s. 89 i nn.). Na trudności te nakłada się jeszcze fakt, że obok skutku prawo karne zna też następstwo. Więcej, następstwo jest wyraźnie określone w przepisach ustawy karnej, gdy skutek jest pojęciem doktrynalnym. Tymczasem w odniesieniu do następstwa doktryna prawa karnego ogłosiła właściwie bezradność poznawczą. Tarapata wyraźnie pisze, że nie ma sensu szukanie jakiejkolwiek ontologicznej definicji następstwa, gdyż w gruncie rzeczy to od arbitralnej decyzji ustawodawcy zależy, czy mamy do czynienia z następstwem, czy ze skutkiem (S. Tarapata, Przypisanie sprawstwa skutku..., s. 79). W zasadzie taki sam wniosek wysnuwa J. Piórkowska-Flieger (Skutek czynu zabronionego..., s. 102 i nn.), dodając tylko, że następstwo jest szczególnym rodzajem skutku, ale o tym, co jest, a co nie jest następstwem, decyduje ustawodawca. Dla niniejszej analizy ważne są spostrzeżenia A. Gimbut, która zauważa, że z następstwem mamy do czynienia w przypadku czynów stypizowanych dwustopniowo, czyli takich, w których w tzw. pierwszym stopniu ustawodawca opisał jakieś zabronione zachowanie, a w drugim uzależnił jego wyższą karalność od określonego następstwa w świecie zewnętrznym (A. Gimbut, Następstwa czynu, od których zależy wyższa karalność w prawie polskim na tle porównawczym, Warszawa 1966, s. 9). Analizowany typ nie jest typem dwustopniowym, mamy więc w nim do czynienia ze skutkiem. Nie zmienia to okoliczności, że o ile następstwo zwykle jest związane z przedmiotem ochrony (głównym czy ubocznym), o tyle w wypadku wykroczenia z art. 81 K.w. związek taki jest dość luźny, jeżeli uznać, że przedmiotem ochrony jest bezpieczeństwo osób i mienia, i dość ścisły, jeżeli uznać, że jest nim należyty stan brzegów wód morskich i śródlądowych. 
Pociąga to za sobą określone skutki na gruncie takich typów jak analizowany. Jeżeli trzymać się poglądu o tym, że skutek musi być powiązany z przedmiotem ochrony, pojawia się wiele wątpliwości, co właściwie jest przedmiotem ochrony i co jest skutkiem. Już w tym miejscu można skonstatować, że $\mathrm{w}$ analizowanym przypadku mamy do czynienia $\mathrm{z}$ typem, który w zakresie deklarowanego przez ustawodawcę przedmiotu ochrony jest ewidentnie czynem z narażenia na niebezpieczeństwo abstrakcyjne i nie musi istnieć żadne niebezpieczeństwo dla życia lub zdrowia ludzi czy mienia. Z drugiej strony jest to też ewidentnie czyn skutkowy, chyba że uznamy, iż to nie uszkodzenie urządzenia jest skutkiem, o który chodzi w przepisie. W literaturze istnieją poglądy, że typy z narażenia na niebezpieczeństwo abstrakcyjne mogą być jednocześnie skutkowe ${ }^{15}$. Jest to możliwe, jednak tylko przy przyjęciu założenia, że skutek stanowiący znamię czynu zabronionego ${ }^{16}$ nie musi dotykać przedmiotu ochrony, lecz że jest to przewidziana $\mathrm{w}$ przepisie zmiana $\mathrm{w}$ świecie zewnętrznym. Do kwestii tej będzie okazja raz jeszcze wrócić po odniesieniu się do przedmiotu czynności wykonawczej, to jego bowiem w interesującym nas zakresie dotyczy wywołana przez sprawcę zmiana w świecie zewnętrznym.

Powyższe ma określone znaczenie dla analizy przedmiotu ochrony. Jak wskazano, bezpieczeństwo osób i mienia jest przedmiotem ochrony, bo taką decyzję podjął ustawodawca. Jednak tym przedmiotem ochrony jest też należyty stan brzegów, a idąc dalej - dobrostan przyrody. Z punktu widzenia czysto systemowego należy zapewne uważać, że pierwsze ze wskazanych dóbr jest główne, drugie poboczne. Tak też napisano wyżej. Z drugiej jednak strony być może warte rozważenia jest nieco odmienne spojrzenie. Wydaje się wszak, że decyzja ustawodawcy o takim, a nie innym umiejscowieniu przepisu nie była dostatecznie przemyślana. Bezpieczeństwo osób i mienia rzeczywiście jest wspólnym mianownikiem

15 Zob. np. S. Tarapata, Przypisanie sprawstwa skutku..., s. 75.

16 A tylko o taki skutek może tutaj chodzić. Trzeba podkreślić, że gdyby przyjąć - nieakceptowaną tu - koncepcję finalną czynu, można byłoby uważać, że skutek jest znamieniem każdego czynu, skoro czyn jest zachowaniem ukierunkowanym na spowodowanie określonego skutku. Zob. H. Welzel, Das deutsches Strafrecht, Berlin 1965, s. 29; A. Zębik, Czyn a przestępstwo ciąłe, Łódź 1971, s. 13; W. Mącior, Czyn ludzki i jego znaczenie w prawie karnym. Zagadnienia podstawowe, Warszawa 1990, s. 63; P. Konieczniak, Czyn jako podstawa odpowiedzialności w prawie karnym, Kraków 2002, s. 400; W. Patryas, Interpretacja karnistyczna. Studium metodologiczne, Poznań 1988, s. 14. Tu mowa jest jednak tylko o skutku stanowiącym znamię czynu zabronionego. 
znakomitej większości przepisów stypizowanych w rozdziale X K.w., jednak art. 81 K.w. chyba tylko dlatego się w nim znalazł, że na pierwszy rzut oka wykazuje jakiś związek z art. 80 K.w. Oba czyny zabronione dotyczą brzegów rzeki wód, ale art. 80 K.w. typizuje zachowania, które zwiększają niebezpieczeństwo powodzi, czyli zdarzenia niebezpiecznego dla życia i zdrowia człowieka oraz mienia, podczas gdy art. 81 K.w. typizuje zachowanie niebezpieczne przede wszystkim dla przyrody. Wydaje się zatem, że przepis ten mógłby z powodzeniem znajdować się w rozdziale XIX K.w.

\section{Określenie czynności sprawczej}

Czynność sprawcza polega na niszczeniu lub uszkadzaniu urządzeń służących do ochrony brzegów wód morskich lub śródlądowych. Niszczenie i uszkadzanie należy rozumieć tak, jak na gruncie art. 288 K.k. i art. 124 K.w. - niszczenie to zatem zachowanie skutkujące unicestwieniem rzeczy lub powodujące, że traci ona cechy rzeczy danego rodzaju, stając się jakąś inną rzeczą ${ }^{17}$. Dla analizowanego typu oznacza to, że niszczeniem jest po pierwsze unicestwienie urządzenia, po drugie tak poważne uszkodzenie, że straci ono właściwości urządzenia ochronnego ${ }^{18}$. Uszkodzeniem jest fizyczne naruszenie substancji urządzenia, także takie, które nie ogranicza funkcji ochronnych ${ }^{19}$. Może ono (nie musi) ograniczyć lub wyłączyć użyteczność urządzeń, lecz nie prowadzi do ich unicestwienia, ani nie sprawia, że przestają być urządzeniami ochronnymi ${ }^{20}$.W tym tkwi różnica między zniszczeniem i uszkodzeniem. W przypadku pierwszego zawsze dochodzi do utraty właściwości ochronnych, w drugim może do niej nie dojść. Znamiona niszczenia i uszkadzania można rozumieć szerzej w odniesieniu do roślinności ochronnej, gdyż w przypadku żywych organizmów podjęcie zachowania, które skutkuje utratą właściwości jako rzeczy danego rodzaju, obejmuje bowiem także pozbawienie życia bez naruszenia integralności fizycznej, np. przez użycie chemikaliów. Z kolei przez uszkodzenie można rozumieć również spowodowanie choroby rośliny.

17 M. Kulik, Przestęstwo i wykroczenie uszkodzenia rzeczy, Lublin 2005, s. 65.

18 Tenże, w: Kodeks wykroczeń..., red. P. Daniluk, s. 527.

19 Tenże, Przestęstwo..., s. 66.

20 Tamże, s. 79; M. Kulik, w: Kodeks wykroczeń..., red. P. Daniluk, s. 527. 


\section{Urządzenia służące do ochrony brzegów}

Nie wnikając szczegółowo w pojęcie urządzeń służących do ochrony brzegów wód morskich lub śródlądowych, trzeba odwołać się do: art. 220 ustawy z dnia 20 lipca 2017 r. - Prawo wodne ${ }^{21}$, który definiuje pojęcie linii brzegowej; art. 2 ust. 1 ustawy z dnia 21 marca 1991 r. o obszarach morskich Rzeczypospolitej Polskiej i administracji morskiej22, stanowiącego, co jest obszarami morskimi Rzeczypospolitej Polskiej; art. 18 oraz 19 i 20 Prawa wodnego, z których pierwszy wprowadza pojęcie wód powierzchniowych i podziemnych, zaś dwa kolejne definiują wody śródlądowe, częściowo przez odwołanie się do art. 22 i 23 Prawa wodnego, które stanowią o śródlądowych wodach powierzchniowych płynących i stojących. Nie przytaczając szczegółowo treści tych przepisów, warto zauważyć, że art. $81 \mathrm{~K} . w$. nabiera treści, gdy odniesie się jego regulacje do przepisów Prawa wodnego, a więc regulacji, które nie dotyczą bezpośrednio deklarowanego przez ustawodawcę przedmiotu ochrony, lecz kwestii związanych z ochroną zasobów naturalnych. Być może zatem, przynajmniej w pewnym zakresie, konstrukcja, o której mowa, tworzy po prostu sankcję karną za naruszenie przepisów administracyjnych dotyczących ochrony środowiska naturalnego i jego zasobów. Jeżeli taka optyka jest uzasadniona, a wydaje się, że tak, byłby to kolejny argument wzmacniający stanowisko, że za uboczny przedmiot ochrony należy w danym przypadku uznać dobrostan środowiska naturalnego. Wydaje się wręcz, że gdyby nie umiejscowienie przepisu w rozdziale dotyczącym bezpieczeństwa osób i mienia, byłoby mało danych, by uważać analizowane wykroczenie za skierowane przeciwko temu dobru prawnemu.

Przepis operuje liczbą mnogą na określenie przedmiotu czynności wykonawczej. Może to sugerować, że konieczne jest zniszczenie lub uszkodzenie więcej niż jednego obiektu. Wydaje się wszakże, że wykładnia funkcjonalna pozwala przyjąć, iż znamię czynnościowe zostaje wyczerpane także $\mathrm{w}$ razie zniszczenia lub uszkodzenia jednego obiektu ${ }^{23}$. Można uznać, że posługiwanie się $\mathrm{w}$ takich wypadkach liczbą mnogą stanowi przykład swego rodzaju maniery ustawodawcy, dość często spotykanej.

\footnotetext{
21 Tekst jednolity: Dz. U. z 2020 r. poz. 310 z późn. zm.

22 Tekst jednolity: Dz. U. z 2020 r. poz. 284 z późn. zm.

23 M. Kulik, w: Kodeks wykroczeń..., red. P. Daniluk, s. 529.
} 
Urządzenia służące do ochrony brzegów nie mają definicji ustawowej. Art. 81 K.w. wymienia jako przykłady umocnienia brzegowe i roślinność ochronną ${ }^{24}$, jednak trudno uznać, że jest to wskazówka wiele wnosząca do rozumienia, czym jest urządzenie ochronne, wszak możliwe są także wszelkie inne urządzenia, które mogą służyć do ochrony brzegów. Zapewne mowa przede wszystkim o urządzeniach wodnych w rozumieniu przepisów Prawa wodnego ${ }^{25}$, ale nie tylko o nich, a także nie o wszystkich elementach uznawanych w prawie wodnym za urządzenia wodne. Spośród urządzeń wodnych wymienionych w powołanym przepisie można wskazać niektóre budowle regulacyjne, niektóre rowy, niektóre mury oporowe $^{26}$. Pojęcie umocnień brzegowych występuje w $\S 2$ pkt 36 rozporządzenia Ministra Transportu i Gospodarki Morskiej z dnia 1 czerwca 1998 r. w sprawie warunków technicznych, jakim powinny odpowiadać morskie budowle hydrotechniczne i ich usytuowanie ${ }^{27}$. Rozporządzenie to dotyczy wyłącznie umocnień brzegowych morskich. W odniesieniu do umocnień brzegów wód śródlądowych nie istnieją żadne regulacje. Pojawia się pytanie, czy można stosować zawarte $\mathrm{w}$ rozporządzeniu definicje do umocnień wód śródlądowych. W literaturze wyrażany jest pogląd, że $\operatorname{tak}^{28}$.

Nie powtarzając szczegółowych uwag zawartych w komentarzach do Kodeksu wykroczeń, należy stwierdzić, że do umocnień brzegowych zasadniczo zalicza się dwie kategorie obiektów - po pierwsze są to budowle morskie wymienione we wskazanym wyżej rozporządzeniu, takie jak opaska brzegowa, ostroga brzegowa, falochron brzegowy, próg podwodny, okładzina, wał przeciwsztormowy i zejście na plażę $e^{29}$. Status wskazanych kategorii urządzeń ochronnych wynika wprost z przepisów ${ }^{30}$. Wydaje się jednak, że katalog ten można i należy uzupełnić na

${ }^{24}$ Tamże; W. Radecki, w: Kodeks wykroczeń..., s. 619; J. Piórkowska-Flieger, w: Kodeks wykroczeń..., red. T. Bojarski, s. 207.

25 Art. 16 pkt 65 Prawa wodnego; M. Kulik, w: Kodeks wykroczeń..., red. P. Daniluk, s. 529.

26 M. Kulik, w: Kodeks wykroczeń..., red. P. Daniluk, s. 529.

27 Dz. U. z 1998 r. Nr 101, poz. 645.

28 J. Piórkowska-Flieger, w: Kodeks wykroczeń..., red. T. Bojarski, s. 207; M. Kulik, w: Kodeks wykroczeń..., red. P. Daniluk, s. 529.

29 M. Kulik, w: Kodeks wykroczeń..., red. P. Daniluk, s. 530.

30 Niezależne od tego, że zna je także literatura przedmiotu. Zob. np. M. Szruba, Modernizacja i budowa umocnień brzegowych, Nowoczesne Budownictwo Inżynieryjne 2019, nr 1-2, s. 29. 
podstawie wiedzy technicznej. Za urządzenia ochronne uznaje się zatem np. tzw. brzegoskłony, rzuty kamienne, kamienne gabiony połączone z roślinnością ochronną, plotki, kiszki z włókniny i faszyny, często łączone z roślinnością ochronną, walce faszynowo-kamienne i siatkowo-kamienne, ostrogi ziemne i kamienne, czyli groble wychodzące z brzegu i wcinające się np. w rzekę, powodujące zmniejszenie erozyjnego oddziaływania nurtu na brzeg, walce z włókien kokosowych montowane u podstawy skarpy brzegowej w celu jej ochrony przed erozją, a także rowy wypełnione kamieniami ${ }^{31}$.

Drugim z przedmiotów czynności wykonawczej jest roślinność ochronna, niekiedy określana mianem umocnień biologicznych, które same w sobie stanowią umocnienia brzegowe ${ }^{32}$. Roślinność ochronna często stosowana jest jako uzupełnienie innych umocnień, ponadto sama w sobie ma wartość ochronną ${ }^{33}$. Wydaje się zatem, że przepis art. 81 K.w., który wyraźnie różnicuje urządzenia ochronne i roślinność ochronną, jest w obecnej postaci nieco anachroniczny ${ }^{34}$. Mógłby stanowić tylko o urządzeniach ochronnych. Zniszczenie lub uszkodzenie takiej roślinności, w sytuacji kiedy miałaby ona samoistne funkcje ochronne, byłoby zniszczeniem lub uszkodzeniem urządzenia ochronnego. Każde zniszczenie lub uszkodzenie takiej roślinności ochronnej, która nie pełni samoistnie żadnej funkcji ochronnej, lecz stanowi tylko uzupełnienie innych urządzeń ochronnych, stanowi uszkodzenie owych innych urządzeń. Wskazane przykłady uzupełnienia urządzeń przez roślinność ochronną zawsze polegają na jakimś fizycznym połączeniu roślinności z urządzeniem. Roślinność ochronna staje się częścią składową urządzenia, stąd jej zniszczenie lub uszkodzenie jest uszkodzeniem urządzenia ${ }^{35}$. Wobec tego wydaje się w zasadzie zbęd-

31 E. Jędryka, Budowle wodne z naturalnych materiatów, Woda - Środowisko - Obszary Wiejskie 2007, t. 7, z. 2b, s. 56; R. Duszyński, Ekologiczne techniki ochrony brzegów i rewitalizacji rzek, Inżynieria Morska i Geotechnika 2007, nr 6, s. 342-346; por. M. Kulik, w: Kodeks wykroczeń..., red. P. Daniluk, s. 530.

32 E. Jędryka, Budowle wodne..., s. 56; M. Kulik, w: Kodeks wykroczeń..., red. P. Daniluk, s. 530.

33 E. Jędryka, Budowle wodne..., s. 56; M. Kulik, w: Kodeks wykroczeń..., red. P. Daniluk, s. 346-348.

34 M. Kulik, w: Kodeks wykroczeń..., red. P. Daniluk, s. 530.

35 Rzadko będzie to uszkodzenie urządzenia, choć a priori nie da się tego wykluczyć. Możliwe, lecz mało prawdopodobne jest, że sprawca tylko uszkadza roślinność ochronną, nie niszcząc jej całkowicie, a mimo to całe urządzenie zostanie $\mathrm{w}$ zupełności zniszczone. Najczęstsze będą przypadki, kiedy zniszczenie lub uszkodzenie roślinności ochronnej skutkuje uszkodzeniem całego urządzenia, z którym roślinność jest połączona. 
ne operowanie znamieniem roślinności ochronnej, wystarczyłoby użycie znamienia urządzenia ochronnego.

Powyższe stwierdzenie może rodzić wątpliwość, czy nie jest możliwe takie uszkodzenie roślinności ochronnej, które jednocześnie nie będzie uszkodzeniem urządzenia ochronnego. Wydaje się, że nie, aczkolwiek biorąc pod uwagę specyfikę uszkodzenia rośliny, można rozważyć, czy ewentualna modyfikacja przepisu nie powinna uwzględnić możliwości (mało prawdopodobnej) uszkodzenia roślinności stanowiącej uzupełnienie innego urządzenia ochronnego, która nie stanowi bezpośrednio materialnego uszkodzenia owego innego urządzenia. Byłoby to możliwe w sytuacji, w której roślinność ochronna uzupełniałaby inne urządzenie ochronne, ale jednocześnie nie stanowiłaby jego części składowej. W takim przypadku uszkodzenie owej roślinności mogłoby ograniczać użyteczność urządzenia jako takiego, choć nie naruszałoby jego substancji.

Taka ewentualność wydaje się o tyle mało prawdopodobna, że nawet gdyby zniszczona lub uszkodzona roślinność ochronna nie stanowiła części składowej urządzenia, to jej zniszczenie lub uszkodzenie w większości przypadków skutkowałaby - być może w pewnym odstępie czasowym uszkodzeniem samego urządzenia, pozbawionego wsparcia roślinności ochronnej. Niemniej można sądzić, że ewentualna modyfikacja analizowanego przepisu winna uwzględniać także mało prawdopodobną okoliczność, że tak się nie stanie.

Przepis art. 81 K.w. mógłby zatem typizować zniszczenie, uszkodzenie lub uczynienie niezdatnym do użytku urządzania służącego do ochrony brzegów. W takim ujęciu przedmiotem czynności wykonawczej byłoby po prostu urządzenie służące do ochrony brzegów. Zniszczenie i uszkodzenie wyjaśniono wyżej, uczynienie niezdatnym do użytku byłoby zaś zachowaniem, które ograniczałoby funkcjonalną wartość urządzenia, nie naruszając jego substancji.

W przypadku kiedy roślinność ochronna sama stanowiłaby urządzenie ochronne, nie byłoby wątpliwości, jak należy rozumieć te znamiona. Gdyby roślinność ta stanowiła część składową innego urządzenia, należałoby każde jej zniszczenie lub uszkodzenie uznawać za uszkodzenie owego innego urządzenia, a uczynienie go niezdatnym do użytku za uczynienie niezdatnym do użytku tego urządzenia ${ }^{36}$. $\mathrm{Z}$ kolei $\mathrm{w}$ - potencjalnie

36 Całkowite lub częściowe. W przypadku uczynienia rzeczy niezdatną do użytku nie ma wątpliwości, że w grę wchodzi zarówno zachowanie całkowicie pozbawiające 
możliwej, choć mało prawdopodobnej sytuacji - gdy roślinność ochronna wspiera funkcjonowanie urządzenia ochronnego, nie stanowiąc jego części, jej zniszczenie, uszkodzenie lub uczynienie niezdatną do użytku miałoby znaczenie prawne tylko wtedy, gdy skutkowałoby zniszczeniem, uszkodzeniem lub uczynieniem niezdatnym do użytku samego urządzenia. $W$ takim układzie poza zakresem zastosowania przepisu pozostałaby sytuacja, w której zniszczenie, uszkodzenie lub uczynienie niezdatną do użytku roślinności nie miałoby żadnego znaczenia dla użyteczności (efektywności) zabezpieczenia jako takiego. Wydaje się, że proponowane brzmienie przepisu uczyniłoby go bardziej odpowiadającym roli, którą w założeniu ma pełnić.

Wyżej wskazano, że art. 81 K.w. tworzy typ skutkowy, będący jednocześnie wykroczeniem z narażenia dobra na niebezpieczeństwo abstrakcyjne. Jest to możliwe wobec faktu, że przedmiotem ochrony deklarowanym przez ustawodawcę jest bezpieczeństwo osób i mienia, a zachowanie ukierunkowane jest na naruszenie obiektu, który nie ma z tym dobrem bezpośredniego związku ${ }^{37}$. Właśnie $\mathrm{w}$ tym momencie aktualizują się podniesione wyżej okoliczności dotyczące tzw. czynów zdatnościowych. W zakresie ewentualnego naruszenia lub narażenia przedmiotu ochrony jest to typ bezskutkowy. Niemniej istnieje skutek, tyle że nie występuje on w zakresie przedmiotu ochrony.

Analiza przedmiotu czynności wykonawczej jest dobrym pretekstem do krótkiego powrotu do problematyki przedmiotu ochrony. Warto spojrzeć na dobro chronione przez pryzmat skutku. Skutek w danym wypadku da się, zgodnie z zaproponowaną przez S. Tarapatę nomenklaturą, zaklasyfikować jako skutek statyczny ${ }^{38}$. Wyżej zauważono, że przedmiotem ochrony ze względu na pozytywną decyzję ustawodawcy jest bezpieczeństwo osób i mienia. Stwierdzono także, iż skutek bezpośrednio nie dotyka tego dobra. Obecnie można powiedzieć więcej - nawet jego zdatność do narażenia tego dobra może być co najwyżej abstrakcyjna. Wyżej wyrażono pogląd, że w przypadku typów skutkowych nie jest konieczne, by skutek atakował przedmiot ochrony. Skutek może dotyczyć innego dobra

przedmiot użyteczności, jak i pozbawiające go jej częściowo. M. Kulik, w: Kodeks wykroczeń..., red. P. Daniluk, s. 80.

37 W. Radecki, w: Kodeks wykroczeń..., s. 620; P. Kozłowska-Kalisz, w: Kodeks wykroczeń..., red. M. Mozgawa, s. 285; W. Jankowski, w: Kodeks wykroczeń..., red. T. Grzegorczyk, s. 345; M. Kulik, w: Kodeks wykroczeń..., red. P. Daniluk, s. 530.

38 S. Tarapata, Przypisanie sprawstwa skutku..., s. 80. 
i nie zmieni to okoliczności, że chronione jest to dobro, na ochronę którego ukierunkowany jest przepis. Jest to istota typów zdatnościowych, o których wspomniano. Jednak w wypadku typu, o którym mowa obecnie, jest jeszcze inaczej. Szczupłe ramy opracowania nie pozwoliły ani na szczegółowe omówienie czynności wykonawczej, ani na dokładną analizę przedmiotu czynności wykonawczej ${ }^{39}$. Nawet na tle tak skrótowego spojrzenia widać, że żaden z przedmiotów czynności wykonawczej w gruncie rzeczy nie służy, a przynajmniej nie służy przede wszystkim do ochrony życia i mienia. Służą one zwłaszcza do ochrony stanu brzegów, a więc ochrony zasobu naturalnego, jakim jest woda.

\section{Problematyka wyłączenia wielości ocen}

Z uwagi na sposób określenia czynności wykonawczej szeroka jest problematyka zbiegu przepisów i zbiegu czynów zabronionych. Wyżej wskazano, że istnienie w tle niejako „ukrytego” przedmiotu ochrony w postaci należytego stanu brzegów wód morskich i śródlądowych może mieć znaczenie dla stosowania reguł wyłączania wielości ocen, w szczególności konsumpcji. Pora przyjrzeć się tej okoliczności w szczegółach. Za dosyć typowy należy uznać zbieg art. 81 K.w. z art. 124 K.w. i odpowiednio art. 288 K.k. (w zależności od wysokości wyrządzonej szkody). Przedmiotem ochrony omawianego czynu zabronionego jest bezpieczeństwo osób i mienia, zaś art. 124 K.w. i art. 288 § 1 K.k. - własność i posiadanie rzeczy. W obu przypadkach w określeniu przedmiotu ochrony pojawia się mienie, jednak w różnym kontekście. W art. 81 K.w. mowa o ochronie mienia, przy czym chodzi o mienie inne niż samo urządzenie ochronne. Wartość majątkowa, jaką przedstawia samo urządzenie (czy roślinność) jest bez znaczenia. W art. 124 K.w. i art. 288 K.k. chodzi natomiast o naruszenie mienia, jakim jest samo urządzenie ochronne. Przepis ten nie obejmuje żadnych ewentualnych negatywnych skutków dla mienia (lub bezpieczeństwa mienia) chronionego przez urządzenia lub roślinność. Wydaje się więc, że jeżeli sprawca, umyślnie niszcząc lub uszkadzając urządzenie

39 W tym zakresie zob. W. Radecki, w: Kodeks wykroczeń..., s. 620; P. Kozłowska-Kalisz, w: Kodeks wykroczeń..., red. M. Mozgawa, s. 285; W. Jankowski, w: Kodeks wykroczeń..., red. T. Grzegorczyk, s. 345; M. Kulik, w: Kodeks wykroczeń..., red. P. Daniluk, s. 530. 
ochrony brzegu zbudowane na cudzej nieruchomości czy też roślinę stanowiącą część roślinności ochronnej, rosnącą na cudzej nieruchomości, wyrządzi szkodę majątkową, zachodzi rzeczywisty realny zbieg wykroczenia z art. 81 K.w. i przestępstwa z art. 288 § 1 lub 2 K.k., rozstrzygany na gruncie art. $10 \mathrm{~K} . w .{ }^{40}$ Kwestią bardziej złożoną jest zbieg z art. $124 \mathrm{~K} . w$. Na pierwszy rzut oka mogłoby się wydawać, że należy go rozwiązywać analogicznie. Jednak zagadnienie jest bardziej złożone. $W$ doktrynie istnieje pogląd, że w ustawowe znamiona czynu z art. $81 \mathrm{~K} . w$ jest wkomponowana szkoda majątkowa w wysokości „wykroczeniowej”, czyli do 500 zł, zatem art. 81 K.w. w zakresie, w jakim typizuje zachowanie umyślne, stanowi przepis szczególny dla art. 124 K.w. ${ }^{41}$

Możliwy jest też jednoczynowy zbieg wykroczenia $\mathrm{z}$ art. 81 K.w. z przestępstwem z art. 131 ustawy z dnia 16 kwietnia 2004 r. o ochronie przyrody ${ }^{42}$, który typizuje m.in. wypalanie łąk, pastwisk, nieużytków, rowów, pasów przydrożnych, szlaków kolejowych, trzcinowisk lub szuwarów wbrew przepisom art. 125 tejże ustawy ${ }^{43}$, ponadto zabijanie zwierząt, niszczenie roślin lub grzybów, a także niszczenie siedlisk roślin, zwierząt lub grzybów. Z uwagi na określenie przedmiotów ochrony obu przepisów ${ }^{44}$ wydaje się, że zbieg ten jest rzeczywisty właściwy. Zastosowanie na podstawie art. $9 \S 1$ K.w. znajdzie art. 131 ustawy o ochronie przyrody ${ }^{45}$.

Możliwy jest zbieg art. 81 K.w. z art. 474 ustawy Prawo wodne, który typizuje wykonanie $\mathrm{w}$ pobliżu urządzeń wodnych lub pomiarowych robót lub czynności zagrażających tym urządzeniom. Wydaje się, że zbieg ten, aczkolwiek rzeczywisty, będzie pomijalny i zastosowanie na zasadzie konsumpcji znajdzie art. 474 Prawa wodnego. Nie inaczej jest w przypadku zbiegu art. 81 K.w. z art. 475 Prawa wodnego, który typizuje czyn

40 M. Kulik, w: Kodeks wykroczeń..., red. P. Daniluk, s. 531.

${ }^{41}$ W. Radecki, w: Kodeks wykroczeń..., s. 621; P. Kozłowska-Kalisz, w: Kodeks wykroczeń..., red. M. Mozgawa, s. 285; W. Jankowski, w: Kodeks wykroczeń..., red. T. Grzegorczyk, s. 345; M. Kulik, Przestępstwo..., s. 266-267.

42 Tekst jednolity: Dz. U. z 2019 r. poz. 1696 z późn. zm.

43 Który wprowadza szereg zezwoleń na zabijanie zwierząt lub niszczenie roślin w związku z realizacją uzasadnionych celów.

44 Po raz kolejny pojawia się zagadnienie określenia przedmiotu ochrony. W przypadku czynu z art. 81 K.w., jak wiadomo, nie pojawia się element ochrony przyrody, choć ujęcie przepisu wyraźnie wskazuje na to, że narażenie środowiska przyrodniczego jest tu w zasadzie oczywistą koniecznością.

45 M. Kulik, w: Kodeks wykroczeń..., red. P. Daniluk, s. 531. 
polegający na tym, że sprawca niszczy lub uszkadza brzegi śródlądowych wód powierzchniowych, brzegi wód morskich, budowle, w tym mury, niebędące urządzeniami wodnymi, tworzące brzeg lub grunty pokryte śródlądowymi wodami powierzchniowymi. Także i w tym wypadku art. 81 K.w. ulegnie konsumpcjit ${ }^{4}$.

Natomiast rzeczywisty właściwy, rozstrzygany na gruncie art. $9 \S 1$ K.w. jest zbieg art. 81 K.w. z art. 477 ust. 6 Prawa wodnego (nieutrzymywanie urządzeń wodnych). Trzeba podkreślić, że ustawowe znamiona obu wchodzących w grę czynów krzyżują się - nieutrzymywanie urządzeń może, lecz nie musi spowodować ich uszkodzenia, zaś urządzenia ochronne mogą być urządzeniami wodnymi. Zbieg zatem jest rzeczywisty, a na podstawie art. 9 $\S 1$ K.w. zastosowanie znajduje art. 477 ust. 6 Prawa wodnego ${ }^{47}$. Przepis ten operuje surowszą karą. Art. 81 K.w. przewiduje grzywnę do 1000 zł lub naganę, zaś 477 ust. 6 Prawa wodnego karę grzywny, co oznacza grzywnę do $5000 \mathrm{zł}$.

Na pierwszy rzut oka za niejasny można uznać stosunek art. 81 K.w. do art. 477 ust. 7 Prawa wodnego. Ten ostatni przepis typizuje zachowanie polegające na tym, że sprawca wbrew przepisowi art. 192 ust. 1 pkt 1 Prawa wodnego ${ }^{48}$ niszczy lub uszkadza urządzenia wodne. Czynność wykonawcza jest $w$ obu przepisach określona identycznie. Odmiennie kształtuje się przedmiot czynności wykonawczej. W art. 81 K.w. są nim urządzenia służące do ochrony brzegów wód morskich lub śródlądowych, w szczególności wszelkie umocnienia lub roślinność ochronna, zaś w art. 477 ust. 7 Prawa wodnego - urządzenia wodne. Jak wspomniano, zakresy tych pojęć krzyżują się, co sprawia, że między wskazanymi przepisami zachodzi zbieg rzeczywisty. Wydaje się, że in concreto możliwa jest konsumpcja. Przepisem konsumującym jest art. 477 ust. 7 Prawa wodnego. Jak wiadomo, cechą reguły konsumpcji jest to, że znajduje ona zastosowanie w realiach konkretnej sprawy, co powoduje, że między tymi samymi dwoma przepisami w jednym stanie faktycznym dochodzi do konsumpcji, w drugim dochodzi do zbiegu rzeczywistego właściwego, rozwiązywanego na zasadzie art. 9 § 1 K.w. To z kolei sprawia, że w gruncie rzeczy sytuacja przedstawia się identycznie jak przy zastosowaniu reguły konsumpcji

46 Tamże.

47 Tamże, s. 532.

48 Ten ostatni przepis po prostu zakazuje niszczenia lub uszkadzania urządzeń wodnych. 
- czyn jest kwalifikowany z art. 477 ust. 6 Prawa wodnego. Okoliczność polegająca na tym, że niejako $\mathrm{w}$ tle przedmiotu ochrony pojawia się element ekologiczny, pozwala uznać, że w razie jednoczynowego wyczerpania ustawowych znamion analizowanego typu wykroczenia i któregoś z przestępstw przeciwko środowisku naturalnemu (art. 181 albo 187 K.k.) art. 81 K.w. zwykle ulegnie konsumpcji ${ }^{49}$.

\section{Zakończenie}

To, że analizowany czyn zabroniony cechuje pewien eklektyzm określenia przedmiotu ochrony powoduje, że wielce prawdopodobne jest krzyżowanie się przepisów na tle stanu faktycznego. Wówczas niemal zawsze przedmiot ochrony w postaci bezpieczeństwa osób i mienia, który nie jest naturalnie powiązany z przedmiotem czynności wykonawczej, będzie tą częścią zestawu ustawowych znamion czynu zrealizowanego przez sprawcę, która nie pokryje się z zestawem określonym $\mathrm{w}$ innym ze zbiegających się przepisów. To sprawia, że zastosowanie reguły specjalności będzie rzadkością, często pojawi się potrzeba rozważenia najtrudniejszej do abstrakcyjnego rozpracowania reguły konsumpcji. Występuje to bardzo często w przypadku skutkowych czynów, w których skutek nie dotyka przedmiotu ochrony. Można rzec, że analizowany przepis jest $\mathrm{w}$ pewnym sensie skazany na pozostawanie $\mathrm{w}$ zbiegu z innymi.

Zapewne przynajmniej części z trudności związanych z interpretacją przepisu można byłoby uniknąć, gdyby przemodelować spojrzenie na przedmiot ochrony i mocniej zaakcentować przyrodniczy charakter typu. Wydaje się wręcz, że sposób określenia przedmiotu czynności wykonawczej i przedmiotu ochrony przemawia za tym, żeby typ znalazł się nie w X, a w XIX rozdziale K.w.

49 M. Kulik, w: Kodeks wykroczeń..., red. P. Daniluk, s. 532. 


\section{Bibliografia}

\section{Źródła}

\section{Akty prawne}

Konwencja Narodów Zjednoczonych o prawie morza, sporządzona w Montego Bay 10 grudnia 1982 r., Dz. U. z 2002 r. Nr 59, poz. 543.

Rozporządzenie Ministra Transportu i Gospodarki Morskiej z dnia 1 czerwca 1998 r. w sprawie warunków technicznych, jakim powinny odpowiadać morskie budowle hydrotechniczne i ich usytuowanie, Dz. U. z 1998 r. Nr 101, poz. 645.

Ustawa z dnia 21 marca 1991 r. o obszarach morskich Rzeczypospolitej Polskiej i administracji morskiej, tekst jednolity: Dz. U. z 2020 r. poz. 284 z późn. zm.

Ustawa z dnia 16 kwietnia 2004 r. o ochronie przyrody, tekst jednolity: Dz. U. z 2019 r. poz. 1696 z późn. zm.

Ustawa z dnia 20 lipca 2017 r. - Prawo wodne, tekst jednolity: Dz. U. z 2020 r. poz. 310 z późn. zm.

\section{Literatura}

Andrejew I., Polskie prawo karne w zarysie, Warszawa 1986.

Andrejew I., Ustawowe znamiona czynu. Typizacja i kwalifikacja przestęstw, Warszawa 1978.

Bojarski M., Giezek J., Sienkiewicz Z., Prawo karne materialne. Część ogólna, Warszawa 2004.

Bojarski M., Radecki W., Kodeks wykroczeń. Komentarz, Warszawa 2016.

Cieślak M., Prawo karne. Zarys systematycznego ujęcia, Warszawa 1994.

Duszyński R., Ekologiczne techniki ochrony brzegów i rewitalizacji rzek, Inżynieria Morska i Geotechnika 2007, nr 6.

Gardocki L., Typizacja uproszczona, Studia Iuridica 1982, t. 10.

Gardocki L., Uproszczone formy penalizacji, Państwo i Prawo 1975, z. 8-9.

Gimbut A., Następstwa czynu, od których zależy wyższa karalność w prawie polskim na tle porównawczym, Warszawa 1966.

Gruszecka D., Ochrona dobra prawnego na przedpolu jego naruszenia. Analiza karnistyczna, Warszawa 2012.

Hryniewicz E., Przestępstwa abstrakcyjnego i konkretnego zagrożenia dóbr prawnych, Warszawa 2012.

Hryniewicz E., Skutek w prawie karnym, Prokuratura i Prawo 2013, nr 7-8.

Jędryka E., Budowle wodne z naturalnych materiałów, Woda - Środowisko - Obszary Wiejskie 2007, t. 7, z. 2b.

Kodeks karny. Część szczególna. Komentarz, red. J. Giezek, Warszawa 2014.

Kodeks karny. Komentarz. Część szczególna, t. 2, red. A. Zoll, Kraków 2006. 
Kodeks karny. Komentarz, red. A. Grześkowiak, K. Wiak, Warszawa 2018.

Kodeks karny. Komentarz, red. M. Filar, Warszawa 2015.

Kodeks karny. Komentarz, red. M. Mozgawa, Warszawa 2017.

Kodeks wykroczeń. Komentarz, red. M. Mozgawa, Warszawa 2009.

Kodeks wykroczeń. Komentarz, red. P. Daniluk, Warszawa 2018.

Kodeks wykroczeń. Komentarz, red. T. Bojarski, Warszawa 2015.

Kodeks wykroczeń. Komentarz, red. T. Grzegorczyk, Warszawa 2013.

Konieczniak P., Czyn jako podstawa odpowiedzialności w prawie karnym, Kraków 2002.

Kulik M., O skutkowym lub bezskutkowym charakterze czynów zabronionych przez art. 182 k.k., Annales Universitatis Mariae Curie-Skłodowska. Sectio G. Ius 2014, t. $61, \mathrm{nr} 2$.

Kulik M., Przestepstwo i wykroczenie uszkodzenia rzeczy, Lublin 2005.

Łabuz T., Sposoby ochrony brzegów morskich $i$ ich wptyw na środowisko przyrodnicze polskiego wybrzeża Bałtyku. Raport [online], WWF 2013, https:/ /www.wwf.pl/ sites/default/files/2017-07/Sposoby\%20ochrony \%20brzeg\%C3\% B3w\% 20 morskich\%20i\%20ich\%20wp\% C5\%82ywu \%20na \%20\%C5\%9Brodowisko\% 20 przyrodnicze\%20polskiego\%20wybrze\%C5\%BCa.pdf [dostęp: 12.12 .2020 r.].

Marek A., Prawo karne, Warszawa 2011.

Mącior W., Czyn ludzki i jego znaczenie w prawie karnym. Zagadnienia podstawowe, Warszawa 1990.

Patryas W., Interpretacja karnistyczna. Studium metodologiczne, Poznań 1988.

Piórkowska-Flieger J., Skutek czynu zabronionego w polskim prawie karnym, Lublin 2019.

Słownik języka polskiego, red. M. Szymczak, t. 1, Warszawa 1979.

System prawa karnego. Przestępstwa przeciwko państwu i dobrom zbiorowym, red.

L. Gardocki, Warszawa 2013.

Świda W., Prawo karne, Warszawa 1989.

Tarapata S., Przypisanie sprawstwa skutku w sensie dynamicznym w polskim prawie karnym, Kraków 2019.

Welzel H., Das deutsches Strafrecht, Berlin 1965.

Wolter W., Nauka o przestępstwie, Warszawa 1973.

Wolter W., Zarys systemu prawa karnego. Część ogólna, t. 1, Kraków 1933.

Wróbel W., Zoll A., Polskie prawo karne. Część ogólna, Kraków 2010.

Zębik A., Czyn a przestępstwo ciągłe, Łódź 1971.

\section{Streszczenie}

Artykuł obejmuje analizę ustawowych znamion wykroczenia niszczenia lub uszkadzania urządzeń służących do ochrony brzegów wód morskich lub śródlądowych. Jest to ciekawy typ czynu zabronionego polegającego na wywołaniu 
abstrakcyjnego zagrożenia dla dobra chronionego. W doktrynie uważa się takie czyny za bezskutkowe, jednak Autor twierdzi, że analizowany czyn ma charakter skutkowy. Z uwagi na konstrukcję typu wywołuje on trudności na gruncie zbiegu przepisów ustawy. Ich rozstrzygnięcie następuje na gruncie tzw. reguł wyłączania wielości, z uwzględnieniem zarówno logicznych, jak teleologicznych zasad wykładni.

Słowa kluczowe: uszkodzenie, zniszczenie, urządzenie służące do ochrony brzegów, ochrona przyrody, odpowiedzialność karna

\section{ADMINISTRATIVE OFFENCE OF DESTRUCTION OR DAMAGE TO DEVICES CONSTRUCTED FOR PROTECTION OF SEA SHORES AND INLAND WATERS (ARTICLE 81 OF THE PETTY OFFENCES CODE)}

\section{Summary}

The article covers the analysis of statutory marks of an administrative offence of destruction or damage to devices constructed for protection of sea shores and inland waters. This is an interesting type of a prohibited act that involves causing an abstract threat to the protected goods. The doctrine considers such acts to be ineffective, but the author believes that the act under analysis is of effective nature. Due to the construction of the type of offence, it causes difficulties on the basis of the overlap of the provisions of the act. Settlement of the Article 81 takes place on the grounds of the so-called rules for excluding a multiplicity, including both logical and teleological rules of interpretation.

Key words: damage, destruction, device constructed for protection of the shores, nature protection, criminal responsibility

\section{ПРАВОНАРУШЕНИЕ, СВЯЗАННОЕ С УНИЧТОЖЕНИЕМ ИЛИ ПОВРЕЖДЕНИЕМ УСТРОЙСТВ, ИСПОЛЬЗУЕМЫХ ДЛЯ ЗАЩИТЫ БЕРЕГОВ МОРСКИХ ВОД ИЛИ ВНУТРЕННИХ ВОДНЫХ ПУТЕЙ} (СТ. 81 КОДЕКСА ПРАВОНАРУШЕНИЙ)

\section{Резюме}

Статья посвящена анализу установленных законом признаков состава правонарушения уничтожения или повреждения устройств, используемых для защиты берегов морских вод или внутренних вод. Это интересный тип уголовного правонарушения, заключающийся в создании абстрактной 
угрозы для блага охраняемого законом. Доктрина рассматривает такие деяния как деяния без правовых последствий, но автор считает, что анализируемое деяние носит результативный характер. Тип конструкции правонарушения вызывает трудности, когда положения закона пересекаются. Их урегулирование происходит на основе, так называемых, правил исключения множественности, включая как логические, так и телеологические правила толкования права.

Ключевые слова: повреждение, уничтожение, устройства, используемые для защиты берегов, охрана окружающей среды, уголовная ответственность 